\title{
Espécies de Phytophthora associadas à gomose em pomares de citros no Estado do Paraná, Brasil
}

\author{
Marilda Pereira Caixeta ${ }^{1}$, William Mário de Carvalho Nunes ${ }^{1}$, Alvaro Figueredo dos Santos², Dauri José Tessmann ${ }^{1}$, \\ João Batista Vida ${ }^{1}$
}

\begin{abstract}
${ }^{1}$ Núcleo de Pesquisa em Biotecnologia Aplicada-NBAe Departamento de Agronomia, Universidade Estadual de Maringá. Maringá/PR; ${ }^{2}$ Embrapa/ Floresta, Colombo/PR.

Autor para correspondência: William Mário de Carvalho Nunes (wmcnunes@uem.br).

Data de chegada: 01/04/2013. Aceito para publicação em: 01/10/2013.
\end{abstract}

\section{RESUMO}

Caixeta, M. P.; Nunes, W. M. C.; Santos, A. F.; Tessmann, D. J.; Vida, J. B. Espécies de Phytophthora associadas à gomose em pomares de citros no Estado do Paraná, Brasil. Summa Phytopathologica, v.39, n.4, p.242-247, 2013.

A gomose dos citros é considerada uma doença de grande importância para a citricultura no Brasil e em nível mundial. A etiologia desta doença compreende um complexo de espécies de Phytophthora. Embora importante, pouco se conhece sobre a gomose nas regiões produtoras de citros no Estado do Paraná. Por isso, este trabalho teve como objetivo identificar espécies de Phytophthora associadas à gomose em pomares de citros no Paraná. Nas regiões Norte, Noroeste e Vale do Ribeira foram retiradas amostras de raízes de plantas com sintomas de gomose e também de solo da rizosfera. Em laboratório, empregando pêra cv. D'anjou como isca e meio de cultivo batata-dextrose-ágar, foram obtidos 21 isolados de Phytophthora spp. Todos os isolados infectaram mudas de limão 'Cravo', reproduzindo os sintomas de gomose e também apresentaram crescimento micelial a $8^{\circ} \mathrm{C}$ e a $36^{\circ} \mathrm{C}$, com exceção do isolado PR20 para $36^{\circ} \mathrm{C}$. "In vitro", esses isolados foram heterotálicos, sendo 20 compatíveis ao tipo padrão A2 e um compatível ao tipo padrão A1.
Vinte isolados formaram esporângios persistentes e papilados, com 25,5 - 62,0 $\mu \mathrm{m}$ de comprimento (C) e 27,9 - 49,6 $\mu \mathrm{m}$ de largura (L) e a relação $\mathrm{C} / \mathrm{L}$ foi de $1,38: 1$. Um isolado (PR20) apresentou esporângios medindo 40,3 - 55,8 $\mu \mathrm{m}$ de comprimento e 27,9 - 37,2 $\mu \mathrm{m}$ de largura, formando esporângios persistentes, papilados ou bipapilados e de formas distorcidas, não formando clamidósporos. A temperatura ótima para crescimento desse isolado foi entre 20 a $28^{\circ} \mathrm{C}$, enquanto para os demais foi de 24 a $32^{\circ} \mathrm{C}$, tendo estes produção abundante de clamidósporos globosos de diâmetro variando entre 21,7 a 43,4 $\mu \mathrm{m}$. De acordo com as características morfofisiológicas apresentadas, dos 21 isolados analisados, 20 pertenceram à espécie $P$. nicotianae e um à espécie $P$. citrophthora. A análise de sequências de genes da região ITS1-5.8S-ITS2 do rDNA e usando o teste de "Single-Strand Conformation Polymorphism" (SSCP), confirmou P. nicotianae e P. citrophthora como as duas espécies de Phytophthora associadas à gomose em pomares de citros no estado do Paraná.

Palavras-chave adicionais: Phytophthora nicotianae, Phytophthora citrophthora, etiologia, Citrus spp.

\section{ABSTRACT}

Caixeta, M. P.; Nunes, W. M. C.; Santos, A. F.; Tessmann, D. J.; Vida, J. B. Phytophthora species associated with root rot in citrus orchards in Paraná State, Brazil. Summa Phytopathologica, v.39, n.4, p.242-247, 2013.

Citrus root rot is considered a disease of great importance to citriculture in Brazil and around the world. The etiology of this disease comprises a complex of Phytophthora species. Although citrus root rot is important, little is known about it in the producing regions of Paraná State, Brazil. Therefore, this study aimed to identify Phytophthora species associated with root rot in citrus orchards in Paraná. In the North and Northwest regions of this state and in Vale do Ribeira, samples were collected from the roots of plants showing symptoms of citrus root rot, as well as from the rhizosphere soil. In the laboratory, employing pear cv. D'anjou as bait and the culture medium potato-dextrose-agar, 21 isolates of Phytophthora spp. were obtained. All isolates infected seedlings of Rangpur lime, reproducing the symptoms of root rot and presenting mycelial growth at $8{ }^{\circ} \mathrm{C}$ and $36{ }^{\circ} \mathrm{C}$, except for the isolate PR20 at $36^{\circ} \mathrm{C}$. In vitro, these isolates were heterothallic, and 20 of them were compatible with the standard type A2, while one of them was compatible with the standard type
A1. Twenty isolates formed papillate persistent sporangia of 25.5 $62.0 \mu \mathrm{m}$ length (C) and $27.9-49.6 \mu \mathrm{m}$ width $(\mathrm{L})$; the $\mathrm{C} / \mathrm{L}$ ratio was 1.38:1. One isolate (PR20) had sporangia of 40.3 - 55.8 $\mu \mathrm{m}$ length and 27.9 - 37.2 width, forming papillale or bipapillate persistent sporangia of distorted forms and not forming chlamydospores. The optimum temperature for the growth of this isolate was between 20 and $28^{\circ} \mathrm{C}$, while for the remaining isolates it was from 24 to $32^{\circ} \mathrm{C}$; the latter had abundant production of globose chlamydospores with diameter ranging from 21.7 to $43.4 \mu \mathrm{m}$. According to the presented morphophysiological characteristics, of the 21 analyzed isolates, 20 belonged to the species $P$. nicotianae and one to the species $P$. citrophthora. Sequence analysis of genes of the rDNA ITS1-5.8SITS2 region, using the test Single-Strand Conformation Polymorphism (SSCP), confirmed $P$. nicotianae and $P$. citrophthora as the two Phytophthora species associated with root rot in citrus orchards in the state of Paraná.

Additional keywords: Phytophthora nicotianae, Phytophthora citrophthora, etiology, Citrus spp. 
A citricultura se constitui numa das mais importantes atividades do agronegócio no Brasil, sendo o País o maior produtor mundial de citros e também líder na exportação de concentrado de laranja (12). Por isso, todas as ações para melhorar as variáveis que compõem a cadeia produtiva da citricultura brasileira são importantes, inclusive aspectos relacionados à sanidade. Entre as mais de 50 enfermidades, que podem ocorrer em citros, a gomose causada por Phytophthora spp. se constitui numa das mais importantes (5). Nas regiões brasileiras onde a citricultura é mais antiga, trabalhos têm relatado a ocorrência de P. nicotianae, P. citrophthora e P. palmivora, associadas à doença (4).

No Estado do Paraná, onde a implantação da citricultura é bem mais recente tem-se constatado, não raro, a presença de plantas com sintomas severos de gomose em pomares comerciais em diferentes localidades. Observações de campo em pomares de tangerinas na região do Vale do Ribeira, revelam ser a gomose o principal problema sanitário, com incidência de até $40,0 \%$ e morte de até $16,0 \%$ de plantas. Nesta região, a doença tem contribuído para o aumento do custo de produção da citricultura, uma vez que as plantas doentes, que não apresentam produção econômica, são substituídas por mudas sadias, associando medidas para desinfestação do solo na cova de plantio. Nas regiões Norte e Noroeste, onde a citricultura foi implantada bem mais recentemente e onde se cultiva basicamente laranjas doces, a incidência de gomose tem sido muito menor (até 8,0 \%), mas também preocupante, uma vez que a doença pode se alastrar e tornar-se um fator de redução de produção.

Embora a gomose seja importante para a citricultura do Paraná, ainda não foram desenvolvidos estudos sobre a etiologia de espécies de Phytophthora associadas à gomose em pomares de citros. Segundo Feichtenberger et al. (4), várias espécies de Phytophthora podem infectar citros: P. nicotianae, P. citrophthora, P. palmivora, P. boehmeria, $P$. cactorum, P.capsici, P. citricola, P. cinnamomi, P. drechsleri, P. hibernales, P. megasperma e P. syringae. É, portanto, importante a identificação das espécies associadas à gomose, pois estas informações servem de suporte para adoção das estratégias de controle da doença. Por isso, esse trabalho teve como objetivo identificar as espécies de Phytophthora associadas à gomose em pomares de citros nas principais regiões produtoras no Estado do Paraná.

\section{MATERIAL E MÉTODOS}

\section{Obtenção dos isolados e teste de patogenicidade}

Pomares de citros de diversas regiões do estado do Paraná foram visitados e realizadas amostragens de plantas apresentando sintomas de gomose. Dessas plantas coletaram-se raízes com necrosamento recente e solo da rizosfera na proporção de aproximadamente 2,0 litros. Para isolamento de possíveis espécies de Phytophthora associadas à doença empregou-se isca, utilizando a metodologia de Matherom e Matejka (10), com algumas modificações. Retirou-se de cada amostra uma subamostra de 50 g de solo+raízes, transferindo-a para copo de vidro de $1000 \mathrm{~mL}$ e acrescentando-se $300 \mathrm{~mL}$ de água destilada-esterilizada, seguido de suave homogeneização por 15 segundos. Em sequência um fruto de pêra, cv. D'anjou, desinfestado com $\mathrm{Na} \mathrm{ClO}$ foi mergulhado na suspensão de solo+raízes. Este material foi mantido em laboratório, sob condições de ambiente (fotoperíodo de $12 \mathrm{~h}$ de luz fluorescente e temperatura variando de 22 a $28^{\circ} \mathrm{C}$ ).

Após cinco a oito dias, quando houve o aparecimento de manchas necróticas no fruto, de 3,0 a 5,0 cm de diâmetro, de coloração marrom escuro e de consistência dura, o fruto foi retirado, lavado em água corrente e procedeu-se o isolamento. Fragmentos de tecido do fruto da região de interseção tecido sadio-tecido necrosado foram retirados e transferidos, diretamente para placas de Petri contendo $15 \mathrm{~mL}$ de meio de cultura batata-dextrose-agar (BDA), acrescido de clorofenicol, nistatina, rifampicina, ampicilina, benomil e pentacloronitrobenzeno (PCNB); todos na concentração $50 \mathrm{ppm}$. Esse material foi mantido sob luz fluorescente contínua, à temperatura ambiente $\left(22\right.$ a $\left.28^{\circ} \mathrm{C}\right)$. Após a formação de colônias com micélio de coloração branca ao redor dos fragmentos de frutos, fragmentos de hifas foram transferidos para placas de Petri contendo meio de cultivo CA (cenoura-agar: $200 \mathrm{~g}$ de cenoura, $18 \mathrm{~g}$ de agar, água q.s.p. $1000 \mathrm{~mL}$ ) para estudos posteriores. Foram obtidos 21 isolados de diferentes regiões geográficas do estado do Paraná: PR1, PR2, PR3, PR4, PR5, PR6, PR7, PR 17, PR18, PR19, PR30, originados de laranja Pera; PR9, PR11, originados de tangerina Ponkan; PR14, PR25, PR26, originados de tangerina Montenegrina; PR20, PR22, originados de laranja doce IAPAR; PR27, PR32, originados de limão Taiti. Os isolados PR1, PR2, PR3, PR4, PR5, PR6, PR7, PR8, PR25, PR26 e PR27 foram originados da região Norte; PR9, PR11, PR14, originados da região do Vale do Ribeira; PR17, PR18, PR19, PR20, PR22, PR27, PR30, PR32, originados da região Noroeste.

Para avaliar a patogenicidade dos 21 isolados, realizaram-se testes em plantas de limão ‘Cravo' (Citrus limonia Osbeck), com três meses de idade, em condição de casa de vegetação semi-climatizada, utilizando o "método de inserção de disco de meio de cultivo contendo micélio" (15). Para produção do inóculo, os isolados foram multiplicados em placas de Petri com o meio CA, a $26^{\circ} \mathrm{C}$, na ausência de luz, durante sete dias.

Para inoculação, no terço médio do caule de cada planta retiraramse três discos da casca de 5,0 mm de diâmetro, distanciados de $10 \mathrm{~cm}$. Em seguida depositou-se em cada ferimento um disco de meio de cultivo CA, com 5,0 mm de diâmetro, contendo micélio de cada isolado. A superfície do disco de meio de cultivo contendo micélio foi colocada em contato com a superfície do floema exposta. Em sequência, o disco da casca retirado foi depositado sobre o disco contendo micélio, e cada ponto de inoculação no caule foi coberto com algodão umedecido em água e protegido com fita plástica. Em sequencia, as plantas inoculadas foram mantidas em câmara úmida a $28^{\circ} \mathrm{C}$ por 48 horas, e, após esse tempo, transferidas para casa de vegetação semi-climatizada. Para cada isolado foram inoculadas duas plantas. Como controle foram inoculadas plantas apenas com disco de meio CA.

Passados 11 dias da inoculação foi retirada a fita plástica e o algodão e, realizada a avaliação, quantificando-se o comprimento diametral da maior lesão na superfície do lenho. Após essa avaliação acompanhou-se a formação de goma nas lesões até aos 60 dias.

\section{Avaliação do crescimento micelial}

O inóculo foi produzido como no ensaio do teste de patogenicidade. Discos de meio de cultivo de 5,0 mm de diâmetro, contendo micélio retirados das margens de colônias foram transferidos para o centro de placas de Petri contendo $15 \mathrm{~mL}$ de meio CA. Em seguida, as placas de Petri foram mantidas em estufa tipo BOD, a 8, 12, 16, 20, 24, 28, 32, 35 e $36^{\circ} \mathrm{C}$, em escuro contínuo. Para cada temperatura foram preparadas cinco placas de Petri (repetições). As placas na estufa BOD foram distribuídas de forma inteiramente casualizada. O crescimento micelial foi quantificado a partir do terceiro dia até o sexto dia medindo-se o diâmetro da colônia em dois sentidos diametralmente opostos. Adicionalmente foi avaliado o aspecto morfológico de cada colônia, observando-se o tipo de colônia e tipo de micélio presente nas culturas a $26^{\circ} \mathrm{C}$. 


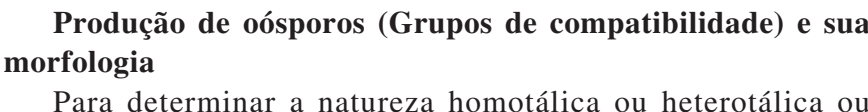
sexualmente infértil dos isolados supostamente de Phytophthora, a formação de oósporos foi avaliada por meio do pareamento destes isolados, com os isolados padrões para os grupos de compatibilidade $\mathrm{A}_{1}$ (isolado 61) e $\mathrm{A}_{2}$ (isolado 65) obtidos da micoteca da Embrapa Floresta/Colombo/PR. Todos os isolados foram cultivados em placas de Petri contendo o meio CA, durante sete dias, em incubadora tipo $\mathrm{BOD}$, em escuro contínuo, a $26^{\circ} \mathrm{C}$. Os isolados $\mathrm{A}_{1}$ e $\mathrm{A}_{2}$ foram pareados com discos de todos os isolados testados, em placas de Petri contendo o meio CA. Os discos foram distanciados $3,0 \mathrm{~cm}$, as placas foram incubadas a $25^{\circ} \mathrm{C}$ em BOD por sete dias, em condições de escuro contínuo. Na região da superfície do meio de cultivo, onde se observou a coalescência de colônias procedeu-se a raspagem para a retirada das estruturas filamentosas formadas, transferindo-as para gota de lactofenol na superfície de lâmina de microscopia e observando ao microscópio óptico para constatação da formação de oósporo. A compatibilidade foi constatada pela presença ou ausência de oósporo, indicando-se o grupo de compatibilidade dos isolados. Usaram-se três repetições para cada combinação de pareamento. Para a avaliação das estruturas reprodutivas mediu-se o diâmetro do oogônio e do oósporo de 50 unidades de cada isolado. Cada anterídio observado foi classificado como anfígeno ou parágino, conforme o ponto de ligação com o oogônio.

\section{Morfologia e dimensão de esporângios e de clamidósporos}

Para avaliação das dimensões dos esporângios, os isolados foram cultivados em CA, durante sete dias, em incubadora, tipo BOD, em escuro contínuo, a $26^{\circ} \mathrm{C}$. Após isso, oito discos de meio de cultivo contendo micélio retirado das margens da colônia foram transferidos para placas de Petri de $90 \mathrm{~mm}$ de diâmetro, contendo $15 \mathrm{~mL}$ de suspensões de extrato de solo não autoclavado. As placas de Petri foram dispostas sob luz fluorescente contínua, a $26^{\circ} \mathrm{C}$, durante 48 horas. O solo utilizado foi do tipo nitossolo eutroférrico e o extrato foi obtido misturando $10 \mathrm{~g}$ do solo em $1000 \mathrm{~mL}$ de água destilada. Após homogeneização, a suspensão permaneceu em repouso por 24 hs para sedimentação da fração mais densa. Em seguida, a parte líquida foi removida e filtrada para retirada da fração grosseira e usada no ensaio experimental. Após 48 horas sob luz fluorescente, nos dois discos de meio de cultivo onde se observou, visualmente, maior desenvolvimento de estruturas filamentosas, retiraram-se alíquotas, transferindo-as para gota de lactofenol em lâmina de microscopia. Observou-se ao microscópio óptico e utilizando-se de lâmina e ocular micrométricas mediram-se as dimensões (comprimento e largura) de 50 esporângios para cada isolado, eleitos casualmente. Além disso, avaliaram-se as profundidade e largura da papila dos esporângios e observou-se a sua morfologia. Para aqueles isolados onde houve formação de clamidósporos foi realizado o mesmo procedimento descrito anteriormente para medir o diâmetro e espessura de parede. Observou-se também a ontogenia dos esporângios ao microscópio com aumento de $100 \mathrm{x}$.

\section{Caracterização molecular}

Para esta caracterização empregaram-se o teste PCR ("Polimerase Chain Reaction") e SSCP (Single-Strand-Coformation Polymorphism). Os isolados foram cultivados em meio líquido de cenoura (200g de cenoura; água destilada q.s.p. $1000 \mathrm{~mL}$ ) por cinco dias, a temperatura de $25^{\circ} \mathrm{C}$ em incubadora tipo BOD, em escuro contínuo. A massa micelial de cada isolado foi separada do meio líquido por filtragem em gaze e colocada em tubos tipo Eppendorf e em seguida preservada em 'freezer' a $20^{\circ} \mathrm{C}$ negativos. Para extração de DNA genômico de cada um dos 21 isolados empregou-se o Kit de extração DNAzol (Invitrogen) e, de acordo com as especificações do fabricante, aproximadamente 50 $\mathrm{mg}$ de micélio de cada isolado foram triturados em nitrogênio líquido, em recipiente de porcelana, até obter-se um fino pó, o qual foi transferido para tubo de Eppendorf de 1,5 mL. Adicionou-se $1 \mathrm{~mL}$ do DNAzol e em seguida as amostras foram centrifugadas a $10.000 \mathrm{~g}$ x 10 minutos. Após a centrifugação, retirou-se o sobrenadante e transferiuo para tubos novos. Para promover a precipitação, foram adicionados $500 \mu \mathrm{L}$ de etanol 100\%. Para solubilização do DNA, os tubos foram abertos por 15 minutos para evaporação total do etanol e em seguida adicionados $0,3 \mathrm{~mL}$ de solução $8 \mathrm{mM}$ de $\mathrm{Na} \mathrm{OH}$. As amostras foram armazenadas a $4^{\circ} \mathrm{C}$.

Para amplificação das regiões ITS1, ITS2 e 5.8S do DNA ribossômico (rDNA) foram empregados os pares de primers ITS5/ ITS2 e ITS4/ITS3, conforme o protocolo descrito por White (19). A reação da polimerase em cadeia (PCR) foi executada utilizando $50 \mu \mathrm{L}$ contendo $39,25 \mu \mathrm{L}$ de água ultrapura, $5 \mu \mathrm{L}$ de $10 \times$ PCR buffer, $1,5 \mu \mathrm{L}$ de $\mathrm{MgCl}_{2}$ a $50 \mathrm{mM}, 1 \mu \mathrm{L}$ de dNTPs a $10 \mathrm{mM}, 1 \mu \mathrm{L}$ de cada primer, $5 \mu \mathrm{L}$ de DNA genômico $0,25 \mu \mathrm{L}$ de Taq ${ }^{\mathrm{TM}}$ DNA polimerase. Todas as reações foram baseadas em 30 ciclos, sendo: 1 minuto a $94^{\circ} \mathrm{C}$; 1 minuto a $61^{\circ} \mathrm{C}$; e 2 minutos a $72^{\circ} \mathrm{C}$. Previamente aos ciclos, as amostras foram submetidas à temperatura de $94^{\circ} \mathrm{C}$ por 1,0 minuto e de um período extra de extensão de 5 minutos a $72^{\circ} \mathrm{C}$ após os 30 ciclos. As reações de amplificação foram conduzidas em um termociclador Tpersonal Whataman Biometra (Biometra GmbH, Goettingen, Alemanha).

\section{Teste de SSCP}

Para amplificação do DNA e realização das análises SSCP dos produtos da PCR foi usada a metodologia descrita por Kong et al. (7), modificada. Para amplificação do DNA dos isolados utilizaram-se o par de "primers" desenvolvido para Oomicetos (Cooke et al. (2): “ primer forward" ITS6: 5' - GAA GGT GAA GTC GTA ACA AGG 3' localizado no gene $18 \mathrm{~S}$ e o "primer reverse" ITS7: 5' - AGC GTT CTT CAT CGA TGT GC - 3' localizado no gene 5.8S do rDNA. A

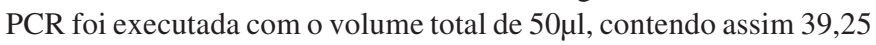
$\mu \mathrm{l}$ de água ultrapura, $5 \mu \mathrm{l}$ de 10 x PCR buffer, $1,5 \mu \mathrm{l}$ de $\mathrm{MgCl}_{2}$ a $50 \mathrm{mM}, 0,1 \mu \mathrm{l}$ de dNTPs a $10 \mathrm{mM}, 1 \mu \mathrm{l}$ de cada um dos primers ("forward e reverse") e $0,25 \mu \mathrm{lde}$ taq ${ }^{\mathrm{TM}}$ polimerase. A reação de PCR se efetivou com o tempo inicial de desnaturação de 2,0 minutos a $96^{\circ} \mathrm{C}$, seguido de 30 ciclos de $94^{\circ} \mathrm{C}$ por 30 segundos, $55^{\circ} \mathrm{C}$ por 45 segundos e $72^{\circ} \mathrm{C}$ por um minuto. Após os 30 ciclos, as amostras foram submetidas à temperatura de $72^{\circ} \mathrm{C}$ por 10 minutos (período extra para extensão). As reações de amplificação foram conduzidas no mesmo equipamento do item anterior.

\section{RESULTADOS E DISCUSSÃO}

\section{Obtenção de isolados em cultura pura e teste de patogenicidade}

Utilizando pêra, cultivar D'anjou, como isca biológica para captura de Phytophthora spp. associadas ao isolamento em cultura pura no meio de cultivo BDA, obtiveram-se 21 isolados com características de Phytophthora spp. O micélio das colônias de todos os isolados apresentou coloração branca e hifas asseptadas. Todos os isolados foram patogênicos às plantas de limão Cravo, onde causaram sintomas característicos de gomose, em diferentes intensidades: formação de 
lesões necróticas no caule, com presença abundante de goma e amarelecimento de folhas. Os isolados PR20, PR14 e PR6 apresentaram alta patogenicidade (lesões medindo de 13 a $16 \mathrm{~mm}$ de comprimento), os isolados PR1, PR4, PR18, PR19, PR25 e PR26 foram moderadamente patogênicos (lesões medindo de 7 a $9 \mathrm{~mm}$ de comprimento) e os isolados PR2, PR3, PR5, PR7, PR8, PR9, PR11, PR17 e PR22 apresentaram baixa patogenicidade (lesões com menos de $6 \mathrm{~mm}$ de comprimento). Muniz et al. (11) observaram que nove isolados de P. nicotianae originados de Citrus sinensis foram patogênicos a mudas de limão cravo e frutos de laranja Pera, causando necrose, com ausência de amarelecimento foliar.

\section{Efeito da temperatura no crescimento micelial}

Houve efeito significativo da temperatura sobre o crescimento micelial dos 21 isolados, com diferenças de comportamento entre eles (Tabela 1). Todos os isolados apresentaram crescimento micelial nas temperaturas entre 8 e $36^{\circ} \mathrm{C}$, com exceção do isolado PR20, que não cresceu à temperatura de $36^{\circ} \mathrm{C}$. A $8^{\circ} \mathrm{C}$, todos os isolados apresentaram crescimento micelial baixo, no máximo de $1 \mathrm{~mm}$ por dia, enquadrando assim no mesmo grupamento, a exceção do isolado PR20 que apresentou maior crescimento micelial (24,6 mm), diferindo significativamente dos demais isolados. Para a maioria dos isolados, o maior diâmetro de colônia foi observado a $24^{\circ} \mathrm{C}$. Para os isolados PR17 e PR19 foi de $28^{\circ} \mathrm{C}$ e para os isolados PR11 e PR18 foi de $32^{\circ} \mathrm{C}$.

$\mathrm{O}$ crescimento micelial em altas temperaturas é um caráter fisiológico que tem sido comumente usado para auxiliar na identificação de espécies de Phytophthora. Phytophthora citrophthora não apresenta crescimento micelial em temperatura de $36^{\circ} \mathrm{C}$, ou acima (3). A temperatura ótima para crescimento micelial de $P$. nicotianae está entre 25 a $30^{\circ} \mathrm{C}(6)$, porém é relatado na literatura crescimento micelial dessa espécie acima de $35^{\circ} \mathrm{C}$ (20). No presente trabalho, observou-se um pequeno crescimento micelial a $36^{\circ} \mathrm{C}$ de todos os isolados de $P$. nicotianae.

\section{Produção e morfologia de oósporos}

Aos sete dias de incubação em temperatura de $26^{\circ} \mathrm{C}$, na ausência de luminosidade, no meio de cultivo CA observou-se a formação de anterídios oogônios e de oósporos. Dos 21 isolados avaliados, 20 deles foram compatíveis com o isolado padrão de $P$. nicotianae, do grupo A2, formando oósporos. Isto indica que esses isolados são heterotálicos, pertencentes ao grupo A1. O isolado PR 20 foi compatível com o isolado padrão do grupo A1, formando oósporos, indicando pertencer ao grupo A2.

Os oogônios de todos os isolados apresentaram diâmetro variando de 20,15 - 35,65 $\mu \mathrm{m}$ (média 27,18 $\mu \mathrm{m}$ ). Os oósporos apresentaram-se globosos, com diâmetro variando de 17,05 - 29,45 $\mu$ m (média 21,62 $\mu \mathrm{m})$. Todos os isolados apresentaram anterídios.

Pela análise morfométrica, dos 21 isolados testados, 20 isolados foram classificados como sendo P. nicotianae e apenas o isolado PR20 como . citrophthora, com base na chave taxonômica de Stamps et. al.(16).

Phytophthora nicotianae foi caracterizada por Waterhouse e Waterston (18) por produzir oogônios esféricos de 20 a $35 \mu \mathrm{m}$ de diâmetro e oósporos com diâmetros de 20 a 30 um e anterídios anfígenos. Por outro lado Muniz et al. (11) observaram em nove isolados de Phytophthora nicotianae oogônios globosos, com 14,8 - 45,9 $\mu \mathrm{m}$ de

Tabela 1. Diâmetro de colônia (mm) de 21 isolados de Phytophthora obtidos de Citrus spp. no meio de cultivo cenoura-agar, utilizando disco de micélio de $5.0 \mathrm{~mm}$ de diâmetro quando cultivados em diferentes temperaturas.

\begin{tabular}{|c|c|c|c|c|c|c|c|c|c|}
\hline \multirow[t]{2}{*}{ Isolados } & \multicolumn{9}{|c|}{ Temperatura $\left({ }^{\circ} \mathrm{C}\right)$} \\
\hline & 8 & 12 & 16 & 20 & 24 & 28 & 32 & 35 & 36 \\
\hline PR 1 & $9.2 \mathrm{~b}$ & $25.6 \mathrm{c}$ & $61.0 \mathrm{a}$ & $68.2 \mathrm{c}$ & $90.0 \mathrm{a}$ & $90.0 \mathrm{a}$ & $89.0 \mathrm{a}$ & $66.0 \mathrm{~d}$ & $18.0 \mathrm{a}$ \\
\hline PR2 & $10.4 \mathrm{~b}$ & $24.2 \mathrm{c}$ & $62.0 \mathrm{a}$ & $74.8 \mathrm{~b}$ & $90.0 \mathrm{a}$ & $87.0 \mathrm{a}$ & $89.0 \mathrm{a}$ & $68.2 \mathrm{~d}$ & $14.0 \mathrm{~b}$ \\
\hline PR3 & $8.8 \mathrm{~b}$ & $26.0 \mathrm{c}$ & $62.4 \mathrm{a}$ & $69.8 \mathrm{c}$ & $90.0 \mathrm{a}$ & $87.4 \mathrm{a}$ & $83.4 \mathrm{~b}$ & $59.8 \mathrm{e}$ & $11.0 \mathrm{c}$ \\
\hline PR4 & $9.6 \mathrm{~b}$ & $20.4 \mathrm{~d}$ & $60.4 \mathrm{a}$ & $73.0 \mathrm{~b}$ & $90.0 \mathrm{a}$ & $85.6 \mathrm{a}$ & $88.8 \mathrm{a}$ & $71.6 \mathrm{c}$ & $12.2 \mathrm{~b}$ \\
\hline PR5 & $7.8 \mathrm{~b}$ & $22.0 \mathrm{~d}$ & $64.0 \mathrm{a}$ & $75.4 \mathrm{~b}$ & $90.0 \mathrm{a}$ & $90.0 \mathrm{a}$ & $86.2 \mathrm{a}$ & $52.4 \mathrm{f}$ & $10.6 \mathrm{c}$ \\
\hline PR6 & $7.4 \mathrm{~b}$ & $22.2 \mathrm{~d}$ & $61.6 \mathrm{a}$ & $72.6 \mathrm{~b}$ & $90.0 \mathrm{a}$ & $90.0 \mathrm{a}$ & $81.8 \mathrm{~b}$ & $48.6 \mathrm{~g}$ & $7.0 \mathrm{~d}$ \\
\hline PR7 & $9.4 \mathrm{~b}$ & $22.0 \mathrm{~d}$ & $62.4 \mathrm{a}$ & $70.0 \mathrm{c}$ & $90.0 \mathrm{a}$ & $90.0 \mathrm{a}$ & $86.0 \mathrm{a}$ & $77.6 \mathrm{~b}$ & $13.2 \mathrm{~b}$ \\
\hline PR 8 & $9.6 \mathrm{~b}$ & $21.4 \mathrm{~d}$ & $62.0 \mathrm{a}$ & $70.4 \mathrm{c}$ & $90.0 \mathrm{a}$ & 86.2 a & $88.0 \mathrm{a}$ & $69.0 \mathrm{~d}$ & $9.8 \mathrm{c}$ \\
\hline PR9 & $7.6 \mathrm{~b}$ & $25.0 \mathrm{c}$ & $62.0 \mathrm{a}$ & $72.6 \mathrm{~b}$ & $90.0 \mathrm{a}$ & $81.0 \mathrm{~b}$ & $82.0 \mathrm{~b}$ & $66.2 \mathrm{~d}$ & $15.4 \mathrm{~b}$ \\
\hline PR 11 & $8.6 \mathrm{~b}$ & $24.0 \mathrm{c}$ & $55.6 \mathrm{c}$ & $68.2 \mathrm{~d}$ & $71.0 \mathrm{a}$ & $82.0 \mathrm{~b}$ & $85.0 \mathrm{~b}$ & $44.0 \mathrm{~h}$ & $8.0 \mathrm{~d}$ \\
\hline PR 14 & $9.4 \mathrm{~b}$ & $22.0 \mathrm{~d}$ & $61.0 \mathrm{a}$ & $69.0 \mathrm{c}$ & $86.0 \mathrm{~b}$ & $81.0 \mathrm{~b}$ & $85.0 \mathrm{~b}$ & $71.0 \mathrm{c}$ & $8.0 \mathrm{c}$ \\
\hline PR 17 & $7.6 \mathrm{~b}$ & $23.6 \mathrm{c}$ & $52.4 \mathrm{~d}$ & $65.2 \mathrm{~d}$ & $86.0 \mathrm{~b}$ & $90.0 \mathrm{a}$ & $83.6 \mathrm{~b}$ & $68.8 \mathrm{~d}$ & $14.2 \mathrm{~b}$ \\
\hline PR 18 & $9.8 \mathrm{~b}$ & $20.8 \mathrm{~d}$ & $61.6 \mathrm{a}$ & $71.2 \mathrm{~b}$ & $84.8 \mathrm{~b}$ & $85.8 \mathrm{a}$ & 88.4 a & $57.8 \mathrm{e}$ & $13.4 \mathrm{~b}$ \\
\hline PR 19 & $9.0 \mathrm{~b}$ & $15.2 \mathrm{e}$ & $50.2 \mathrm{~d}$ & $70.6 \mathrm{~b}$ & $85.4 \mathrm{~b}$ & $90.0 \mathrm{a}$ & $82.6 \mathrm{~b}$ & $77.2 \mathrm{~b}$ & $7.8 \mathrm{~d}$ \\
\hline PR20 & $24.6 \mathrm{a}$ & $37.2 \mathrm{a}$ & $51.6 \mathrm{~d}$ & $60.2 \mathrm{e}$ & $72.0 \mathrm{c}$ & $62.6 \mathrm{c}$ & $38.4 \mathrm{c}$ & $8.4 \mathrm{i}$ & $5.0 \mathrm{~d}$ \\
\hline PR22 & $10.0 \mathrm{~b}$ & $24.6 \mathrm{c}$ & $53.8 \mathrm{c}$ & $75.6 \mathrm{c}$ & $89.0 \mathrm{a}$ & $84.2 \mathrm{~b}$ & 86,2 a & 80.4 a & $12.2 \mathrm{~b}$ \\
\hline PR25 & $10.0 \mathrm{~b}$ & $31.2 \mathrm{~b}$ & $57.2 \mathrm{~b}$ & 80.4 a & $90.0 \mathrm{a}$ & $87.0 \mathrm{a}$ & $81.0 \mathrm{a}$ & 80.0 a & $14.4 \mathrm{~b}$ \\
\hline PR26 & $10.0 \mathrm{~b}$ & $27.6 \mathrm{c}$ & $58.4 \mathrm{~b}$ & $70.8 \mathrm{c}$ & $90.0 \mathrm{a}$ & 87.6 a & $86.0 \mathrm{a}$ & 80.6 a & $14.6 \mathrm{~b}$ \\
\hline PR27 & $10.8 \mathrm{~b}$ & $24.2 \mathrm{c}$ & $54.4 \mathrm{c}$ & $70.2 \mathrm{c}$ & $90.0 \mathrm{a}$ & $90.0 \mathrm{a}$ & $86.8 \mathrm{a}$ & $82.4 \mathrm{a}$ & $19.4 \mathrm{a}$ \\
\hline PR30 & $10.4 \mathrm{~b}$ & $27.4 \mathrm{c}$ & $58.0 \mathrm{~b}$ & $73.6 \mathrm{~b}$ & $90.0 \mathrm{a}$ & $90.0 \mathrm{a}$ & $85.8 \mathrm{a}$ & $76.0 \mathrm{~b}$ & $9.0 \mathrm{~d}$ \\
\hline PR32 & $9.6 \mathrm{~b}$ & $26.0 \mathrm{c}$ & $51.6 \mathrm{~d}$ & $74.4 \mathrm{~b}$ & $90.0 \mathrm{a}$ & $90.0 \mathrm{a}$ & $86.0 \mathrm{a}$ & $76.2 \mathrm{~b}$ & $7.6 \mathrm{~d}$ \\
\hline
\end{tabular}

Os dados são média de cinco repetições, quando seguidas pela mesma letra na coluna pertencem ao mesmo grupamento (Scott-Knot a 5\% de probabilidade) (CV 4,69 \%). 
diâmetro (média 26,4 $\mu \mathrm{m}$ ) contendo oósporos apleróticos, medindo 11,5

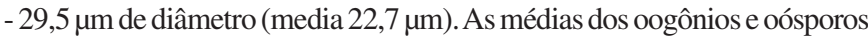
de cada isolado estão de acordo com os intervalos apresentados por Waterhouse e Waterston (18) e Muniz et al.(11), em relação a P. nicotianae.

Dimensão e morfologia de esporângios e clamidósporos

Para comprimento (C) e largura (L) dos esporângios houve diferenças entre os isolados, sendo $65,8 \mu \mathrm{m}$ o maior comprimento observado (isolado PR20) e 25,5 $\mu$ m (isolado PR3) o menor. A maior largura foi de 49,6 $\mu \mathrm{m}$ (isolado PR4) e a menor foi de 18,6 $\mu \mathrm{m}$ (isolado PR2). A relação C/L foi de 1,38:1.

A profundidade média da papila foi de $6,1 \mu \mathrm{m}$ e a abertura média de 5,8 $\mu \mathrm{m}$. De acordo com Waterhouse (17), estas dimensões estão dentro daquelas preconizadas para $P$. nicotianae. Muniz et al. (11) caracterizando nove isolados de Phytophthora originadas de Citrus spp. no estado de Alagoas classificaram-nos na espécie $P$. nicotianae, pois as dimensões dos esporângios e suas papilas também correspondem àquelas observadas por Waterhouse (17). Santos et al. (13) também classificando espécies de Phytophthora associada à doença em acácia negra no Brasil, encontraram resultados semelhantes para dimensões de esporângios identificando o patógeno como P. nicotianae. Embora Erwin e Ribeiro (3) citem para $P$. nicotianae intervalos de dimensões de esporângios um pouco menores que os encontrados nesse trabalho, relataram que pequenas variações podem ocorrer dentro de uma espécie.

Todos os isolados formaram clamidósporos em abundância no meio de cultivo CA, com exceção do isolado PR 20, que não formou este tipo de esporo neste meio de cultivo. Os clamidósporos eram esféricos, terminais ou intercalares, diâmetro variando de 21,7 43,4 $\mu \mathrm{m}$ com paredes lisas, espessura entre 1,2 - 3,1 $\mu \mathrm{m}$. Características semelhantes foram encontradas para clamidósporos produzidos por $P$. nicotianae (1). Somente 35 espécies de Phytophthora produzem clamidósporos (14), sendo que $P$. nicotianae os produz abundantemente (3).

\section{Caracterização molecular - PCR e SSCP}

Os segmentos do gene 5.8S-ITS do rDNA amplificados dos 21 isolados de Phytophthora apresentaram o mesmo tamanho, de aproximadamente 600 pares de base para o par de "primer ITS4/ ITS3" e de aproximadamente 350 pares de base para o par de "primer ITS5/ITS2". A similaridade dos isolados baseada em segmentos amplificados com os "primers ITS3/ITS4" foi de 90 a $100 \%$ entre os 21 isolados, no entanto essa similaridade entre os isolados de P.nicotianae foi de 99 a 100\%. A menor homologia foi encontrada para o isolado PR20 $(90 \%$, identificado como $P$. citrophthora), enquanto que a maior homologia foi para os demais isolados identificados como P. nicotianae, isto é de 99 a $100 \%$. A região ITS é a região mais sequenciada para o gênero Phytophthora $(8,9,20)$, devido ao elevado nível de variações, maior que das regiões SSU “Small Subunit" e LSU "Large Subunit" do rDNA. O grau de variabilidade nas sequências de rDNA pode ser usado na classificação específica e subespecífica. Lee e Taylor (8) ao estudarem a diversidade filogenética da região ITS de 27 isolados de Phytophthora (cinco espécies) observaram que existe maior similaridade entre isolados de $P$. capsici e $P$. citrophthora, do que isolados de $P$. palmivora e $P$. megakarya e que espécie $P$. cinnamomi distinguiu se gradativamente das demais. Entre as espécies $P$. nicotianae e $P$. citrophthora os autores observaram também pouca similaridade sendo assim fáceis de serem identificadas.

A árvore filogenética inferida pelo método de máxima parcimônia, resultante do consenso de cinco árvores mais parcimoniosas, mostrou que os isolados de citros originados do Estado do Paraná formaram dois grupos com suporte pelo teste de bootstrapt de $100 \%$ (Figura 1). O grupo I foi formado pelo isolado PR20 e o grupo II pelos isolados PR1, PR2, PR3, PR4, PR5, PR6, PR7, PR8, PR9, PR17, PR18, PR19, PR25, PR26, PR27, PR30, PR32. Esses dois grupos formaram um clado com bootstrapt de $100 \%$, o qual incluem as espécies do GenBank P. citrophthora e $P$. nicotianae $=$ P. parasitica .

Para a análise SSCP (Figura 2), todos os isolados avaliados apresentaram padrão de bandas SSCP. Dos 21 isolados, 20 deles formaram bandas uniformemente distribuídas com o ponto mais alto do que 6.1 e o mais baixo do que 8.6 para o ladder SSCP. Esses resultados estão de acordo com a chave de classificação proposta por Kong et al. (7), onde os respectivos valores apontam para a espécie $P$. nicotianae. Um isolado teve suas bandas com o ponto mais alto em 7.9 e o mais baixo em 9.0 para o ladder SSCP. Esses resultados também estão de acordo com a chave de classificação proposta por Kong et al. (7) indicando o isolado ser da espécie Phytophthora citrophthora.

De acordo com os resultados das análises das características morfofisiológicas e moleculares de 21 isolados originados de plantas de pomares de Citrus spp. no Estado do Paraná com sintomas de

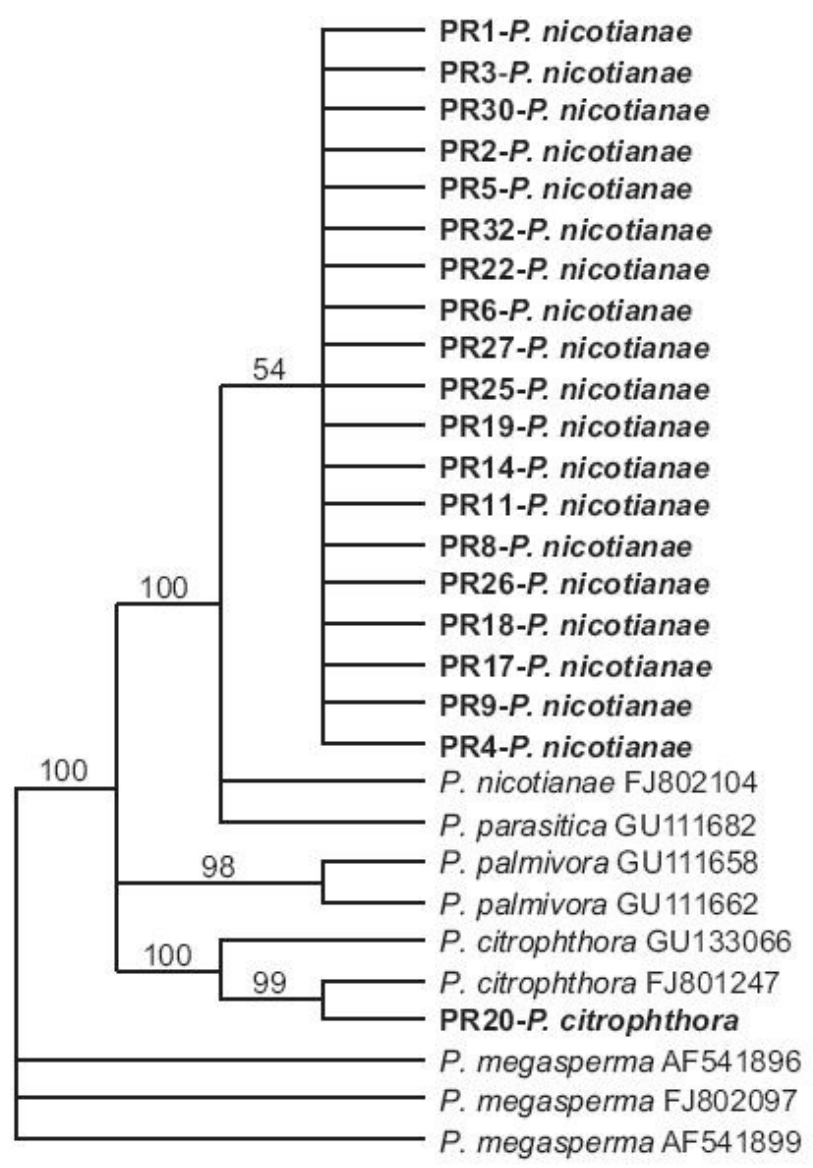

Figura 1. Árvore filogenética consenso inferida pelo método de máxima parcimônia a partir de sequências de DNA das regiões ITS1 e parte do gene 5.8S do rDNA de isolados de Phytophthora spp. de citros. Os números sobre os ramos indicam a porcentagem de repetições da análise de bootstrap, nas quais as repetições foram observadas (1000 repetições). As sequências de rDNA dos isolados em negrito foram obtidas neste trabalho, enquanto as demais sequências foram obtidas do GenBank (com o número de acesso). 


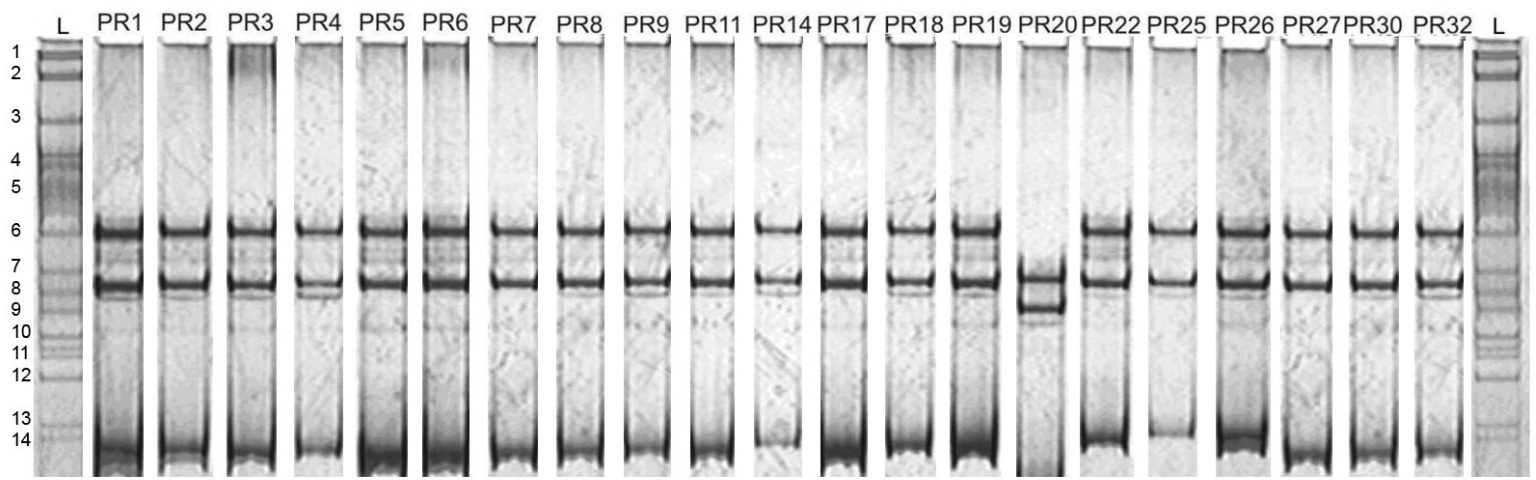

Figura 2. Alinhamento de padrões de bandas single-strand conformational polymorphism (SSCP) de isolados de Phytophthora citrophthora (PR20) e P. nicotianae (demais isolados) originados de Citrus spp.

gomose, 20 se enquadraram como $P$. nicotianae e um isolado como P. citrophthora. Ambos os grupos foram patogênicos a mudas de limão 'Cravo'.

\section{AGRADECIMENTOS}

À Coordenação de Aperfeiçoamento de Pessoal de Nível Superior (CAPES), ao Conselho Nacional de Desenvolvimento Científico e Tecnológico (CNPq) e ao Programa de Pós-Graduação em Agronomia da Universidade Estadual de Maringá (PGA/UEM) pelo apoio financeiro concedido.

\section{REFERENCIAS BIBLIOGRÁFICAS}

1. Alves, T. C. A. Caracterização Morfofisiológica e Molecular de isolados de Phytophthora da Acácia Negra (Acacia mearnsii De Wild) na Região Sul do Brasil. Dissertação Mestrado, Universidade Estadual de Maringá, PR, 70p. 2008.

2. Cooke, D.E.L., Drenth, A.; Duncan, J.M.; Wagels, G.; Brasier, C.M.A. A molecular phylogeny of Phytophthora and related Oomycetes. Fungal Genetics and Biology, Sam Diego, v. 30, n. 1, p. $17-32,2000$.

3. Erwin, D. C.; Ribeiro, O. K. Phytophthora diseases worldwide. St. Paul: The Americam Phytopathological Society. 1996.

4. Feichtenberger, E.; Bassanezi, R. B.; Spósito, M. B.; Belasque JR, J. Doenças dos citros. In: Bergamin Filho, A. e outros; Manual de Fitopatologia - doenças das plantas cultivadas. Sao Pau1o, Ed. Agron. Ceres, v. 2, p. 239-269. 2005.

5. Feichtenberger, E.; Spósito, M. B. Doenças fúngicas dos citros: Manejo integrado. Visão Agrícola , USP, ESALQ. v. 2. p. 44-47, 2004.

6. Holliday, P. Fungus Diseases of Tropical Crops. Cambridge Univ. Press, Cambridge, U.K. 607 p. 1980.

7. Kong, P.; Hong, C.; Richardson, P. A.; Gallegly, M. E. Singlestrand conformational polymorphism of ribosomal DNA for rapid species differentiation en genus Phytophthora. Fungal Genetics and Biology. V. 39, p. 238 - 249, 2003.

8. Lee, S.B.; Taylor, J.W.; Phylogeny of five fungus-like protoctis- tam Phytophthora species, inferred from the internal transcribed spacers of ribosomal DNA. Molecular Biology and Evolution, Oxford, v. 9, n. 2, p. 636 - 653, 1992.

9. Lee, S.B.; White,T.J.; Taylor, J.W. Detection of Phytophthora species by oligonucleotide hybridization to amplified ribosomal DNA spacers. Phytopathology., St.Paul, v. 62, p. 177-181, 1993.

10. Matheron, M. E.; Matejka, J. C. Effect of sodium tetrathiocarbonate, metalaxyl and fosetyl-Al on development and control of Phytophthora root rot of citrus. Plant Disease. St. Paul, V. 75, p. 264-268, 1991.

11. Muniz, M.F.S.; Queiroz, F.M.; Menezes, M. Caracterização de Isolados de Phytophthora patogênicos a Citros sinensis no Estado de Alagoas. Fitopatologia Brasileira, Brasília, v. 29, p. 201 204, 2004.

12. Neves, M.F.; Jank, M.S.; Lopes, F.F.; Trombim, V.G. Ações para aumentar a competitividade da cadeia de laranja no Brasil. Laranja, Cordeirópolis, v.27, n. 2, p. 213 -229, 2006.

13. Santos, A.F.; Luz, E.D.M.N.; Souza, J.T. Phytophthora nicotianae: agente etiológico da gomose de acácia-negra no Brasil. Fitopatologia Brasileira, Brasília, v.30, p.81-84, 2005.

14. Smith, A. L. Biology of chlamydospores of Phytophthora ramorum. $140 \mathrm{~F}$, Thesis (Master of Scienc in Botany and Plant Pathology) Oregon States University, Oregon, 2007.

15. Siviero, A.; Furtado, E. L.; Machado, M. A. Métodos de inoculação de Phytophthora parasitica em citros. Laranja, Cordeirópolis, v. 23, n. 1,p. 203-219, 2002a.

16. Stamps, D. J.; Waterhouse, G. M.; newhook, F. J.; Hall, G. S. Revised tabular key to the species of Phytophthora. Mycological Papers, Wallingford, v. 162 , n. 1, p. $1-28,1990$.

17. Waterhouse, G.M. Key to the species of Phytophthora de Bary. Kew, Commonweath Mycological Institute Mycol. Pap 92. 1963.

18. Waterhouse, G.M.; Waterston, J.M. Phytophthora nicotianae var. nicotianae. Commonw. Mycol. Inst. Descriptions of Pathogenic Fungi and Bacteria. No. 34. 2pp. 1964.

19. White, T.J.; Bruns, T.; Lee, S.; Taylor, J. Amplification and direct sequencing of fungal ribosomal RNA genes for phylogenetics. In: INNIS, M.A.; GELFAND, D.H.; SNINSKY, J.J.; White, T.J. (eds), PCR Protocols: A Guide to Methods and Applications. Academic Press, San Diego, p.315-322, 1990.

20. Zhang Z. G.; Li, Y. Q.; Fan, H.; Wang Y. C.; Zheng, X.B. Molecular detection of Phytophthora capsici in infected plant tissues, soil and water. Plant Pathology, v. 55, p. 770-775, 2004. 